\title{
A practical example: how alcohol screening and brief intervention can work in a real-life New Zealand primary-care environment
}

\author{
Susan Paton ${ }^{1 *}$, John McMenamin², Kristen Maynard ${ }^{1}$ \\ From International Network on Brief Interventions for Alcohol Problems (INEBRIA) Meeting 2011 \\ Boston, MA, USA. 21-23 September 2011
}

New Zealand has a high level of acute alcohol-related harm compared with other countries. In the most recent alcohol use survey, $61.6 \%$ of New Zealand drinkers aged 16-64 years reported heavy episodic drinking at least once in a 12 -month period, and $12.6 \%$ reported weekly heavy episodic drinking. There is substantial multinational evidence, and growing New Zealand evidence, showing that alcohol screening and brief intervention (SBI) in primary-care and emergency-department (ED) settings is an efficacious and cost-effective approach to reducing alcohol-related harm among people with heavy episodic drinking. Despite this, SBI is significantly underutilized in New Zealand. This implementation description demonstrates how SBI has been integrated successfully into general practice in the Whanganui region of New Zealand. In 2010, the Alcohol Advisory Council of New Zealand (ALAC) provided support to the Whanganui Regional Primary Health Organization (WRPHO) to implement an alcohol SBI approach that involved asking all patients $\geq 15$ years about their alcohol consumption, offering brief advice to those identified as risky drinkers, and, where appropriate, referring patients to specialist services. This approach used a reminder system on the front page of electronic patient notes and an advanced form in the patient management system. In just under a year, $43 \%$ of all patients $\geq 15$ years enrolled in the WRPHO had been asked about their alcohol consumption, with 36 percent of these patients receiving a brief intervention or specialist referral. The WRPHO project highlights how SBI can work in a New Zealand primary-care setting and its potential efficacy for reducing alcohol harm.

AAlcohol Advisory Council of New Zealand, Wellington, New Zealand

Full list of author information is available at the end of the article

\section{Author details}

${ }^{1}$ Alcohol Advisory Council of New Zealand, Wellington, New Zealand. ${ }^{2}$ Whanganui Regional Primary Health Organization, Whanganui, New Zealand.

Published: 9 October 2012

doi:10.1186/1940-0640-7-S1-A52

Cite this article as: Paton et al:: A practical example: how alcohol screening and brief intervention can work in a real-life New Zealand primary-care environment. Addiction Science \& Clinical Practice 2012 7(Suppl 1):A52.
Submit your next manuscript to BioMed Central and take full advantage of:

- Convenient online submission

- Thorough peer review

- No space constraints or color figure charges

- Immediate publication on acceptance

- Inclusion in PubMed, CAS, Scopus and Google Scholar

- Research which is freely available for redistribution
C Biomed Central 